\title{
Factors Influencing the Effectiveness of Bilingual Educational Programs: The Prospects of Pilot Programs in Georgia
}

\author{
Shalva Tabatadze \\ Center for Civil Integration and Inter-Ethnic Relations, Tbilisi, Georgia \\ East European University, Tbilisi, Georgia
}

\begin{abstract}
Multilingual Education Programs Regulation was adopted and the implementation of bilingual educational reform started in Georgia in 2010. The paper presents research results on readiness of non-Georgian schools to implement multilingual educational programs effectively. The research studied the important factors influencing the effectiveness of bilingual educational programs, specifically (1) type of program, (2) human resources of schools and teachers professional development, (3) bilingual education as shared vision for all school stakeholders, and (4) community and parental involvement in designing and implementation of bilingual educational programs. The following research methods were used during the research: (1) quantitative and qualitative content analysis of bilingual educational programs of 26 non-Georgian schools of Kvemo Kartli and Samtskhe-Javakheti regions of Georgia, (2) quantitative survey of non-Georgian school principals through questionnaires, and (3) quantitative survey of non-Georgian schools' teachers of different subjective groups through questionnaire. The study revealed that schools are implementing mostly "weak" bilingual educational programs. The schools implementing bilingual educational programs do not have sufficient human resources, bilingual education is not a shared vision for all school stakeholders and parents and community are not actively involved in designing and implementation of the programs.
\end{abstract}

Keywords: Georgia, bilingual education, ethnic minorities, bilingual program effectiveness, non-Georgian schools

\section{Introduction}

The research findings are mostly positive about the effects of bilingual education on children's language awareness and cognitive functioning (Bekerman, 2005). Skutnabb-Kangas and Garcia (1995) identified several positive effects of bilingual education: (1) competence in at least two languages, (2) equal opportunity for academic achievement, and (3) cross-culturality and positive attitudes toward self and others. Despite this advantage, bilingual education is still considered as a controversial issue among the education policy makers (Bekerman, 2005). There are several reasons for this controversy. The effectiveness of bilingual education is influenced by the type of the program, as well as by many other intervening factors.

Shalva Tabatadze, chairman, Center for Civil Integration and Inter-Ethnic Relations; associate professor, Ph.D. candidate, Faculty of Humanities and Social Sciences, East European University. 
This paper presents the research results on bilingual education programs in Georgia. The aim of the research was to investigate the readiness of non-Georgian schools to implement bilingual educational programs effectively. The first part of the paper describes theoretical framework of the research. Second part presents bilingual educational reform in Georgia. Third part of paper is devoted to the research methodology, research results and discussions, and implications of research results.

\section{Theoretical Framework for the Study}

\section{Typology of Bilingual Educational Programs}

Colin Baker (2006) proposed the distinction between "strong" and weak" forms of bilingual educational programs. The "weak" programs mostly ignore the importance of students' native language and are the main reasons of academic underachievement of minority students (Cummins, 2000). There are several other important factors influencing the effectiveness of bilingual education in terms of language learning, academic achievement, and cognitive development (Cummins, 2000). Skutnabb-Kangas (2000) as well as other bilingual education researchers developed bilingual education programs typology based on worldwide experience. The 10 most widely used bilingual education programs are presented in Table 1 from existed typology.

Table 1

Typology of Bilingual Education Programs

MONOLINGUAL FORMS OF EDUCATION FOR BILINGUALS

\begin{tabular}{|c|c|c|c|c|}
\hline Type of Programs & Language Minority & Majority Language & Assimilation/Subtractive & Monolingualism \\
\hline $\begin{array}{l}\text { MAINSTREAMING/SUBMERSION } \\
\text { (Structured Immersion) }\end{array}$ & Language Minority & $\begin{array}{l}\text { Majority Language } \\
\text { with “pull-out” L2 } \\
\text { lesson }\end{array}$ & Assimilation/Subtractive & Monolingualism \\
\hline $\begin{array}{l}\text { MAINSTREAMING/SUBMERSION } \\
\text { with Withdrawal Classes/Sheltered } \\
\text { English/Content-based ESL } \\
\end{array}$ & Language Minority & $\begin{array}{l}\text { Majority Language } \\
\text { (forced, no choice) }\end{array}$ & Apartheid & Monolingualism \\
\hline SEGREGATIONIST & Language Minority & Majority Language & Assimilation/Subtractive & Monolingualism \\
\hline \multicolumn{5}{|c|}{ WEAK FORMS OF BILINGUAL EDUCATION FOR BILINGUALS } \\
\hline Type of Program & $\begin{array}{l}\text { Typical Type of } \\
\text { Child }\end{array}$ & $\begin{array}{l}\text { Language of the } \\
\text { Classroom }\end{array}$ & $\begin{array}{l}\text { Societal and Educational } \\
\text { Aim }\end{array}$ & $\begin{array}{l}\text { Aim in Language } \\
\text { Outcome }\end{array}$ \\
\hline TRANSITIONAL & Language Minority & \begin{tabular}{|l|} 
Moves from Minority \\
to Majority Language
\end{tabular} & Assimilation/Subtractive & \begin{tabular}{|l|} 
Relative \\
Monolingualism
\end{tabular} \\
\hline $\begin{array}{l}\text { MAINSTREAM with Foreign } \\
\text { Language Teaching }\end{array}$ & Language Majority & \begin{tabular}{|l|} 
Majority Language \\
with L2/FL lessons
\end{tabular} & Limited Environment & \begin{tabular}{|l|} 
Limited \\
Bilingualism \\
\end{tabular} \\
\hline SEPARATIST & Language Majority & \begin{tabular}{|l|}
$\begin{array}{l}\text { Minority Language } \\
\text { (out of choice) }\end{array}$ \\
\end{tabular} & Detachment/Autonomy & \begin{tabular}{|l|} 
Limited \\
Bilingualism
\end{tabular} \\
\hline \multicolumn{5}{|c|}{ STRONG FORMS OF BILINGUAL EDUCATION FOR BILINGUALISM AND BILITERACY } \\
\hline Type of Program & $\begin{array}{l}\text { Typical Type of } \\
\text { Child }\end{array}$ & $\begin{array}{l}\text { Language of the } \\
\text { Classroom }\end{array}$ & $\begin{array}{l}\text { Societal and Educational } \\
\text { Aim }\end{array}$ & $\begin{array}{l}\text { Aim in Language } \\
\text { Outcome }\end{array}$ \\
\hline IMMERSION & Language Minority & $\begin{array}{l}\text { Bilingual with initial } \\
\text { emphasis on L2 }\end{array}$ & $\begin{array}{l}\text { Pluralism and } \\
\text { Enrichment. Additive }\end{array}$ & $\begin{array}{l}\text { Bilingualism \& } \\
\text { Biliteracy }\end{array}$ \\
\hline $\begin{array}{l}\text { MAINTENANCE/HERITAGE } \\
\text { LANGUAGE }\end{array}$ & Language Minority & $\begin{array}{l}\text { Bilingual with } \\
\text { emphasis on L1 }\end{array}$ & $\begin{array}{l}\text { Maintenance, Pluralism } \\
\text { and Enrichment. Additive }\end{array}$ & \begin{tabular}{|l|} 
Bilingualism \& \\
Biliteracy
\end{tabular} \\
\hline TWO WAY/DUAL LANGUAGE & $\begin{array}{l}\text { Mixed Language } \\
\text { Minority \& } \\
\text { Majority } \\
\end{array}$ & Minority and Majority & $\begin{array}{l}\text { Maintenance, Pluralism } \\
\text { and Enrichment. Additive }\end{array}$ & $\begin{array}{l}\text { Bilingualism \& } \\
\text { Biliteracy }\end{array}$ \\
\hline MAINSTREAM BILINGUAL & Language Majority & \begin{tabular}{|l|} 
Two Majority \\
Languages Pluralism
\end{tabular} & $\begin{array}{l}\text { Maintenance, Biliteracy } \\
\text { and Enrichment. Additive }\end{array}$ & Bilingualism \\
\hline
\end{tabular}

Note. Adapted from Baker, 2006, pp. 215-216. 
The study used this typology of bilingual educational programs to analyze the pilot bilingual education programs in Georgia.

\section{The Factors Influencing on Effectiveness of Bilingual Education}

Colin Baker in his textbook "Bilingual Education and Bilingualism” (2006) suggested to address the issue of effectiveness of bilingual education from four different perspectives. The suggestion came based on literature review and researches in the field. The issue of effectiveness of bilingual education can be discussed from the following perspectives: (1) individual student level, (2) particular classroom level, (3) school level, and (4) type of bilingual program.

First, there is effectiveness at the level of the individual child. Within the same classroom, children may respond and perform differently. Second, there is effectiveness at the classroom level. Within the same classroom and type of bilingual educational program, classroom may vary considerably. Third, effectiveness is often analyzed at the school level. What makes some schools more effective than others even within the same type of bilingual education program and with similar student characteristics? Fourth, beyond the school level there can be aggregations of schools into different types of program (e.g., transitional compared with heritage language programs)... (Baker, 2006, pp. 260-261)

The type of bilingual education program is seen as important factor influencing the program effectiveness. The previous chapter discussed the "strong" and "weak" forms of bilingual education. The research findings proved that "weak" forms of bilingual education programs are ineffective. The programs aimed at to ignore the importance of native language are main reason for minority student's academic underachievement (Cummins, 2000). However, only the choice of "weak" or "strong" bilingual educational programs cannot guarantee effectiveness of the program. The other important factors influencing the effectiveness of bilingual program should be considered. The following factors are important for bilingual program effectiveness even for "strong" bilingual education programs: (1) human resources; (2) shared vision, mission and goals by school administration and teachers on bilingual education; and (3) parental involvement in school life in general and in designing and implementation of bilingual educational program.

Human resources are important factor for effectiveness of bilingual education (Varghese, 2004). The issue of human resources can be divided into components: (1) school leadership and administration, (2) teachers. The school leadership needs several important traits and knowledge to lead bilingual program effectively, particularly: (1) School principal should be instructional leader, should know curriculum approaches and language teaching methods and able to deliver the approaches to the teachers (Shaw, 2003, in Baker, 2006); (2) School principals should be inspirational leaders. They should be able to develop bilingual education program and models, formulate the vision and mission of their school and develop strategic plan for school; (3) School leaders should be effective administrators and managers, as the "Not only... inspire, motivate, support and communicate well with staff, they also identify, secure and mobilize human, financial and material resources (Montecel \& Cortez, 2002, in Baker, 2006, p. 315).

The second important component of human resources is teachers and their professional development. Haworth et al. (2004) pointed out that literature does not clearly determine the importance of teachers in developing young children's bilingualism. This is explained by the dominance of Krashen's (1981) theories, "which hold that fluency in another language is gained through a process of natural acquisition, rather than through conscious learning” (p. 302). Chomsky (1965) pointed out that children can construct language only in 
the natural settings (Lenneberg, 1967) and thus it is critically important to engage children in play-based activities. The only person, who can create natural setting for students and engage them in play-based activities, is a teacher. Thus, teacher's preparation and training is the most important component of bilingual education reform. As Varghese (2004) pointed out "The highly politicized and debated nature of bilingual educations serves a determining factor in the formation of the professional roles of bilingual teachers” (p. 223). At the same time professional roles of bilingual education teachers are influenced by societal forces created by local context and their personal life and experience (Varghese, 2004). Teacher without high qualification is important threat for effectiveness of bilingual education program. The bilingual education teachers should know modern teaching methods, should have positive attitudes toward bilingual education and minority students, and should be "pedagogue, linguist, innovator, intercultural communicator... (Benson, 2004, in Baker, 2006, p. 314). The bilingual education teacher should conduct a lot of extracurricular activities, assure parental and community involvement in school and classroom life and at the same time should be bilingual and role model for students. It is very hard to meet all these standards.

Bilingual education as shared vision and mission of school and community, is an important factor for effectiveness of bilingual education programs. It is crucially important, that schools have school mission toward bilingual education and strategic plan of school to achieve designed goals for the effectiveness of bilingual educational programs. The school mission, strategic plan and goals should be shared by school administrators, teachers, parents, and community. It is utmost important that all stakeholders have positive attitudes toward bilingual education.

"Parental involvement" is the important component for success of such programs related ethnic minority education (Perna \& Swail, 2000). On the one hand parents are important factors for successful implementation of bilingual education program as they can influence greatly political situation for bilingual education and ensure readiness of ethnic minority students to be involved in these programs (Tabatadze, 2008a). The parent involved in designing and implementation of bilingual educational program can be the most effective mechanism for quality assurance in such programs. On the other hand parental education and involvement is part of a social capital, which is important for ethnic minorities for success not only in education, but also in the future life (Perna \& Titus, 2005). In sum, the study of Perna and Titus (2005) revealed positive relation between the parent involvement as social capital and ethnic minority students educational achievements. Thus, bilingual educational programs, which are able to involve parents in it, are a promising approach to addressing the problem of non-achievement of ethnic minority students due to lack in State language proficiency (Tabatadze, 2008a).

\section{Bilingual Educational Reform in Georgia}

Georgia is located on the Black Sea's eastern coast at the crossroads of Western Asia and Eastern Europe. Georgia borders Armenia, Azerbaijan, Russia, and Turkey. Georgia has a population of about 4,585,874 (Department of Statistics of Georgia, 2002). Georgia is a multiethnic country. Ethnic minorities are composed of 15.8\% of the total population (2002 state census). There are two large ethnic groups Armenian and Azerians compactly residing in two regions of Georgia. Six point five percent of population are Azeri, 5.7\% are Armenian, and $1.5 \%$ are Russian. In terms of religion, the population is predominantly Orthodox Christian (83.9\%), with a group of Muslims (9.9\%). Approximately 53\% of the population lives in urban areas (Tabatadze, 2010b). 
The educational system in Georgia is comprised of preschool, general, and tertiary education, as well as secondary vocational education and training. General education is offered in three levels: primary education (grades 1 to 6), basic education (grades 7 to 9), and secondary education (grades 10 to 12). There are 2,084 public and 230 private schools in Georgia with approximately 560,000 school students (Tabatadze \& Gorgadze, 2014).

Georgian public schools have different language of instructions. Out of 2,084 public schools of Georgia, there are 213 public schools with language of instruction other than Georgian. There are 77 non-Georgian sectors in public schools. Table 2 provides information about the distribution of non-Georgian schools in regions of Georgia.

Table 2

Non-Georgian Schools by Regions of Georgia-2013

\begin{tabular}{lcccc}
\hline Region & Azerbaijani & Russian & Armenian & Total \\
\hline Tbilisi & 1 & 2 & 1 & 4 \\
Kakheti & 4 & 1 & & 5 \\
Samtskhe-Javakheti & & 4 & 96 & 100 \\
KvemoKartli & 80 & 4 & 20 & 104 \\
Total & 85 & 11 & 117 & 213 \\
\hline
\end{tabular}

Note. Adapted from Ministry of Education and Science of Georgia, 2013.

Multilingual Education Program Regulation was adopted by the Ministry of Education and Science of Georgia on August 20, 2010 (Tabatadze, 2010c). The approval of the Regulations as well as formulation of the multilingual education programs for Georgia particularly was the result of considerable work done by local and international experts and organizations for at least six to eight years (Grigule, 2010). The several project and initiatives were implemented during this period, several models of bilingual education were developed and piloted, methodological and teaching materials were developed as well as local experts and trainers are trained (Grigule, 2010).

The various bilingual education programs were piloted and evaluated in the context of Georgia from 2006. The most important project "Multilingual Education Program" was implemented by international non-governmental organization from Switzerland "CIMERA" with financial support of Organization for Security and Cooperation in Europe High Commissioner on national Minorities. The project was implemented during two academic years in 12 public schools of Kvemo Kartli and Samtskhe-Javakheti regions of Georgia (Grigule, 2010). In 2008, the Ministry of Education and Science developed the "National Minority Integration through Multilingual Education” document, basing on which, on March 31st of 2009, the Ministry of Education and Science approved the "Multilingual Education Support Program".

The implemented project and activities, developed policy documents as well as prepared local human resources and accumulated experience enabled the Ministry of Education and Science of Georgia to adopt regulations for bilingual education programs. The regulations proposed the following six multilingual educational programs to public schools:

Developmental (enrichment) Multilingual Educational Program—subjects and subject groups provided by the national curriculum are taught equally on both state and national languages (50 to 50\% or 40 to $60 \%$ ) and equally high language competence is achieved in both state and national languages. The program is similar to 
enrichment bilingual educational program proposed by Skutnabb-Kangas.

Transitional Multilingual Educational Program—study process is carried out on both state and native languages. Although, studies on state language is scaling up and step by step transition on state language takes place. The program is similar to transitional bilingual educational program proposed by Skutnabb-Kangas. The program is referred as "weak" bilingual education program. However, the program can be effective in Georgian context in the regions of compact settlements of ethnic minorities. This issue will be discussed in depth in analytical part of the paper.

Multilingual Educational Program to Support Native Language — subjects and subject areas determined by national curriculum are taught on state language. Native language is taught as a subject.

Multilingual Educational Program to Support State Language—subjects and subject groups provided by the national curriculum are taught on national language. State language is taught as a subject with maximum hourly demand and varying proportion of the curriculum being taught in the state language. The program is similar to heritage language bilingual educational program proposed by Skutnabb-Kangas. The program is referred as "strong" bilingual educational program in the typology. However, the program can be ineffective in Georgian context in the regions of compact settlements of ethnic minorities. This issue will be discussed in depth in analytical part of the paper.

Dual Language Multilingual Educational Program—subjects and subject groups provided by the national curriculum are taught equally on both state and minority languages. Contingent of students is equally divided and represent the Georgian language students as well as non-Georgian language students. The program is similar to dual language bilingual educational program proposed by Skutnabb-Kangas.

Mixed Languages Multilingual Educational Program—study process starts on language, which in most cases is pupils' second language (Russian, for instance). After the initial development of literacy in the second language, (1) subjects on state language or (2) subjects on native and state language are introduced aiming at development of state language, mother-tongue, and other languages necessity for pupils. This program is specific for Georgian context and implies the transformation of the Russian schools into bilingual/multilingual schools.

The public schools can choose the program based on their need assessment, human resources as well as social environment. Public schools can develop their own multilingual education programs; however, the program should be approved by the Ministry of Education and Science of Georgia (Multilingual Education Programs Regulation, 2010).

The amendments and additions were adopted in the "Law on General Education" on December 15, 2010. The term "multilingual education" was officially written in the article two of the law with the following explanation: "Multilingual Education-Education, which aims at development of pupil's language competences in various languages. It implies the organization of the teaching process in educational system to improve the process of acquisition and effective usage of these languages” (Law of Georgia on General Education, 2005).

\section{Research Methodology}

The research aimed at to evaluate the readiness of non-Georgian schools to implement multilingual educational programs effectively. The research studied the important factors influencing the effectiveness of bilingual educational programs, specifically (1) type of program, (2) human resources of schools and teachers 
professional development, (3) bilingual education as shared vision for all school stakeholders, and (4) community and parental involvement in designing and implementation of bilingual educational programs. The following research questions were studied: (1) What type of bilingual educational programs do non-Georgian schools of Kvemo Kartli and Samtskhe-Javakheti regions implement to achieve high competences of their students in native and second languages, high academic achievements and to develop social skills sufficient for their social integration? (2) Are non-Georgian schools ready to implement effective bilingual education program? (3) Do they have sufficient human resources as well as shared vision toward bilingual education to implement the programs effectively? (4) Are parents involved in designing and implementation of bilingual education programs?

\section{Research Design}

The mixed research method was employed during the research study. Thus, the research combined quantitative and qualitative research techniques and approaches. Particularly, two research methods were used: (1) document content analysis and (2) survey. The 26 applications of bilingual education programs from Kvemo Kartlis and Samtskhe-Javakheti regions submitted at the Ministry of Education and Science of Georgia were studied during the document quantitative and qualitative content analysis. The survey for teachers and schools principals was conducted as well. Three hundred and sixty-six teachers and 155 schools principals of non-Georgian schools participated in the survey.

Opportunity of participation in the survey was offered to all the non-Georgian schools located in the target districts (Akhalkalaki, Ninotsminda, Tsalka, Akhaltsikhe, Marneuli, Bolnisi, and Gardabani). By the time of the survey there were total of 216 non-Georgian schools across Georgia. Out of 216 schools 189 non-Georgian schools were located in the above-mentioned target regions (Ministry of Education and Science of Georgia, 2011). As part of the research, principals of all 189 non-Georgian schools received questionnaires. Out of all the schools, principals of 155 schools (82.01\%) agreed to fill out the research questionnaire. High response rate and participation of more than $80 \%$ of all the schools allow for the generalization of the research findings.

As part of the research, separate questionnaires were sent to teachers of non-Georgian schools. According to the 2008 data of the National Center for Teacher Professional Development Center, there were total of 6,541 teachers in all non-Georgian schools of Georgia. In the target districts, the number of teacher amounted to 5,400 teachers (Tabatadze, 2008b). For the purposes of teacher survey stratified sampling was applied. The sample was drawn from all the non-Georgian schools of the regions compactly resided by ethnic minorities-Kvemo Kartli and Samtskhe-Javakheti. Specifically, sample was drawn from the teachers employed at the non-Georgoan schools in Akhaltsikhe, Akhalkalaki, Ninotsminda, Tsalka, Marneuli, Bolnisi, and Gardabani. The following stratification principles were used for the survey: (1) Twenty percent of all the village schools in each district participated in the survey and (2) minimum one teacher of the following subject areas participated in the survey: (a) primary level, (b) math, (c) natural sciences, (d) social sciences, (e) sport/physical education and arts, and (f) foreign languages. Village schools were selected by random sampling. Every fifth village school participated in the survey.

The size of the sample was 366. The objective of the survey was to study how actively the teachers and parents are involved in the programs of multilingual education and what their attitudes are towards these 
programs. Seven percent of the total number of the teachers in minority schools participated in the survey. Teachers participating in the survey represented all the districts of the regions compactly resided by ethnic minorities, both city and village schools of all the districts, teachers of all the subjects, as well as teachers representing all three levels of general education: primary, basic, and secondary education. Schools were selected by mixed method. All the schools from the cities participated in the selection. Village schools were selected by random selection - every fourth school from the list participated in the survey. In sum, teachers of 56 schools participated in the survey, which makes $30 \%$ of all the minority schools in the district where researches have been conducted.

\section{Limitations of the Study}

Most of the factors that define the level of effectiveness of the bilingual education programs were studied in the study. However, there are other important factors that affect the quality of the bilingual programs. Such factors are: social-economic status of the family, status of the language of instruction and its reputation among the local community, etc.. Within this study, it was impossible to control all the factors mentioned. Therefore, such factors as social-economic status of the student's family and the status of the language of the instruction were not researched in this study. However, irrespective of the positive and negative influence above-mentioned factors may have, effectiveness of the bilingual program can be achieved if the school selects the "strong" program, has the qualified teaching and administrative staff, has well-articulated and widely shared mission and goals and ensures active involvement of the parents and community in the school life. These factors may not be the full guarantee of the effectiveness of the bilingual program; however, they are necessary precondition of the success of the bilingual programs.

\section{Findings of the Study, Discussion, and Recommendations}

The study presents several noteworthy findings: (1) Most of the pilot schools implement so-called "weak" bilingual education programs; (2) schools do not have enough human and financial resources to implement bilingual education programs; (3) school administrations demonstrate no readiness to implement this kind of programs; (4) bilingual education programs are seen as the ones imposed by the Ministry of Education and they are not reflected in the mission, goals and strategic plan of the school; (5) bilingual education is not shared vision of the school community, parents, and teachers of the schools; and (6) parent participation in the implementation of the bilingual education programs as well as in school life in general is very minimal. Below these findings will be described briefly.

\section{Types of Bilingual Education Programs Implemented in Pilot Schools}

There are several bilingual educational programs implemented in Georgia in pilot schools. The analysis of bilingual programs as well as analysis of language of instruction in non-Georgian schools revealed the following typology of bilingual educational programs in Georgia (see Table 3).

The submerssion programs are really important and need further research in Georgian context. The number of submersion programs as well as number of non-Georgian students is dramatically increased especially in Kvemo Kartli region (Ministry of Education and Science, 2011). Submersion programs and their impact have not been empirically studied in Georgia. However, the practice and research in the world reveal negative outcomes of 
such programs. Submerssion impies sending non-Georgian kids to the Georgian schools with the zero-competency of the Georgian language. Gvadaluppe Waldes (1998) draws on the research and points out that students in submersion programs do not develop such skills as critical thinking, questioning, and collaborating. It also hinders the cognitive development of a child as the child's competencty in the language of learning is limited and it hinders his cognitive development as well. Research suggests that dropout rates are very high in schools with submerssion programs (Waldes, 1998, in Baker, 2006). Carrasquillo and Rodriguez (2002) also emphasize the ineffectiveness of the submerssion programs. Submerssion programs are considered worldwide as extreme forms of billingual education. It is important to conduct empirical research in Georgia and study the impact of the submmersion programs. This will contribute to the development of the research in this field.

Table 3

Bilingual Education Program Typology in Georgia

Submerssion (Georgian Schools);
Prestigious-Emmigrational (Russian schools with teaching state language as a subject);
Non-Georgian schools with minority language only instructions (Non-Georgian schools, the language of instruction is only
native language of ethnic minorities. The state language as well as foreign language is taught as a subject).
"Weak” Bilingual Educational Programs
Supporting State Language program Minority Language with teaching state language as a subject-“Weak” program in
Georgian context due to demographic situation and language environment);
Transitional Programs (Can become "strong” program in Georgian context);
Mixed Programs;
Supporting Native Language Bilingual Program;
"Strong” Bilingual Educational Programs;
Dual Bilingual Educational Program;
Enrichment Programs.

Nobody questions the inefficiency of the native language monolingual programs. Graduates of these such programs cannot integrate in Georgia's political, social, economic, and cultural life (International Crisis Group, 2006; European Center for Minority Issues, 2009). Introduction of the billingual programs became the response to the urgent need of reforming such schools. Billingual education is seen as an efficient strategy to improve the quality of education in the minority schools and help their graduates better to integrate in the Georgian society.

It should be mentioned that Georgia has another model of billingual education. There are 14 Russian schools and 135 Russian-language sectors in Georgia with total of 28,260 students enrolled (3,748 students in Russian schools and 24,512 students in Russian language sectors). Based on the year 2007 statistical data of the Ministry of Education of Georgia there are only 4,732 ethnically Russian students in Georgia. This data suggests that Russianm language is not a native language for the big part of the students of Russian schools. It is difficult to get the accurate number of such students as quite often in Georgia the first language spoken does not correspond with the ethnicity. For example, Russian is the native language for certain part of Armenian citizens of Georgia as their parents had received education in Russian and therefore the latter became the first language spoken in the family. Despite this peculiarity, the number of the students at Russian school with the native language other but Russian is quite high. This means that for the most of the strudents of the Russian schools the language of instruction is neither the native, or dominant language. This model can be defined as a "prestigious emigration model" (Tabatadze, 2010a). This model contains three different problems: (1) Similar to the submersive programs, the language of instruction is different from the native language which as discussed earlier has negative 
consequences; (2) similar to the native language model, students get their education in the language different from the state one, which creates the problem of the integration of the graduates in the Georgian society; and (3) finally, this model of "prestigious emigration" leaves no other chance to the school graduates but to emigrate in the neighboring countries. This can be explained by the fact that the graduates of Russian schools have very low chances of integration into the Georgian society, as well as the level of their competitiveness to succeed in their career is very low. Thus, these schools educate the students who are competitive in foreign countries and not in Georgia and add to the already existing brain-drain from Georgia. Given only to this third problem, "emigration model" needs to be revised in order to minimize above-mentioned negative consequences.

Education research questions the effectiveness of the "weak" billingual education programs too. Programs supporting the state and native languages will not be effective in Kvemo Kartli and Samtskhe Javakheti as they have entirely non-Georgian environment outside the schools. Therefore, other social agents (such as families, community, church, neighborhood, etc.) do not play the supporting role to the billingual education and the school remains to be the only agent in this process. Hence, these "weak" billingual programs have no enough capacity to make positive impact in the regions compactly resided by ethnic minorities. These regions have been purposely selected as the target of this research. Twelve schools out of 26 target schools selected "weak" form of billingual education program (nine schools in Samtskhe-Javakheti and three schools in Kvemo Kartli). Selection of the "weak" programs was explained by the limited teacher resources the schools have. Given to the circumstances outlined above, it can be hardly expected that these "weak" programs work effectively in the regions compactly resided by ethnic minotiries. The same kind of programs can be defined as "strong" programs in Tbilisi as the environment is Georgian and therefore it may represent the analogy of the heritage language support program as given in the Scutnab-Kanjas classification.

It is very interesting to analyze the so-called "transitional" billingual education program in the context of Georgia. Out of the 26 target schools three schools selected this "transitional” model (all three schools are located in Kvemo Kartli region only). As part of the "transitional” billingual education programs, students learn the subjects in their native languages in the beginning years of the schooling and shift to the full-Georgian language instruction at a later stage. Such approach enables the schools to ensure the proper academic development of the students and smooth shift to the full-Georgian instruction after the language competency of the students in the native language is high enough. "Transitional" billingual education programs are considered to be the "week" programs in the US and Great Britain as they are believed to have little positive impact (Moreover, as a result of the evidenced ineffectiveness of the "trasitional" billingual education programs, no more public funding was allocated for their implementation. It was argued that "transitional" billingual programs are ineffective for the following reasons: (1) For the full acquizition of the language and smooth transition to the non-native language instruction, students need much more time. Given to the insufficient amount of time allocated, students suffer from academic problems at a later stage; (2) minority languages have much lower status than majority languages which lowers the self-esteem of the students and hinders their academic progress and succcess; (3) majority of the teachers are monolingual and are competent only in the majority language. The success of these programs mainly depend on the existance of the billingual teachers who can speak both majority and minority languages when needed; (4) given to the quick shift to the majority-language instruction, students remain at the low academic level in their native language as well (Garcia, 1991; Ovando, Collier, \& Combs, 2003; Creese, 2004; Baker, 
2006). These arguments are very powerful. However, it should be mentioned that the Georgian context significantly differs from the US and Great Britain due to the following reasons: (1) The status of the minority languages in Kvemo Kartli and Samtskhe-Javakheti is quite high. Therefore, students cannot be expected to develop low self-esteem or negative attitudes towards their mother tongue if they study in their native language; (2) majority of the teachers in non-Georgian schools are monolingual, but in the minority rather than the majority language; (3) both in Kvemo-Kartli and Samtskhe-Javakheti the social environment outside the school is fully non-Georgian. Having considered these differences it can be argued that given the proper planning and implementation, "transitional” billingual programs can be very effective in the monority regions of Georgia. For effectiveness of the program transitional program should be implemented in primary as well as on basic school level and the entire shift to the state language can be done only on high school level. However, the human resources are important for transitional programs. The main aim of the schools implementing transitional model should be professuional development of their teachers. Monolingual teachers should become bilinguals themselves.

Out of the 26 target schools four schools selected mixed billingual education programs (three schools in Samtskhe-Javakheti and one school in Kvemo Kartli). Previously the language of instruction was Russian in three schools, and Georgian, in one school. The case of the Georgian school is very interesting. This school selected mixed program, however, in practice this is a totally innovative program and can be defined as a “double-submerssion” program for the minority students. Majority of the students in Aklalkalaki Georgian school are ethnically Georgians. Introduction of the billingual (Russian-Georgian) program was seen as the instrument for attacting more ethnically Armenian students. Russian-Georgian billingual program puts the ethnic minortity students under the "double-submerssion", as for the majority of the Armenian students, neither Georgian nor Russian is the native language and accordingly start the schooling with the two languages of instruction they do not speak. Hence, it can be easily predicted how negative the impact of the “double-sumberssion” program is for Aremenian students. Above-mentioned Russian-Georgian billingual program at the Georgian school in Akhalkalaki can have different implications for the Georgian and Russian students. From their perspective, this program can be defined as a dual billingual program.

In general, mixed billingual education programs can possibly play important role in substituting Russian submerssion and prestigious-migration programs. Nevertheless, the program contains certain risks mainly related to the multiple languages used in it. As it was mentioned, Russian is not the native language for some students. Therefore, the schools are facing three imprortant tasks they have to accomplish: They have to ensure that Armenian students have opportunity to receive education in the native language in the beginning stage; they also have to ensure that students are learning the state language which is Georgian; and finally they have to fulfull the Russian-language component of the program. This complicated approach becomes even more challenging if consider the new policy of the Ministry of Education and Science to strenthen the teaching of English language at the secondary schools. As a result of this policy, instruction of the English language will be starting from grade 1 in all the schools in Georgia, including the minority schools (National Curriculum and Assessment Center, 2011). In this context, proper planning and implementation of the school language policy is very important.

"Strong" billingual education programs are the most effective ones. However, only introduction of such types of the programs cannot guarantee their success. Out of the 26 target schools only seven schools selected the 
"strong” billingual programs. Among these seven programs six programs are formative ones, whereas the seventh one can be classified as a dual billingual program. Six of these programs were introduced in Kvemo-Kartli and one in Samtskhe-Javakheti.

Dual billingual education program is a very interesting one. This program implies that students to be taught are both representatives of majority and minority. Dual billingual education programs are widely spread across the world and work quite effectively. Given to the demographic composition of Georgia, it is a matter of discussion whether dual programs can be effectively implemented in the regions compactly resided by ethnic minorities. It is more likely that such programs can be effectively implemented in cities like Akhaltsikhe, Rustavi, and Tbilisi where the schools have both ethnically Georgian and non-Georgian students. Dual programs can be also implemented in the regions compactly resided by ethnic minoties. However, the scale of implementation can be very limited given to the demographic composition of these regions.

\section{Lack of Qualified Human Resources}

The findings of this study suggest that in the beginning stage of the billingual programs schools do not have adequate human resources. This problem was evident both based on the analysis of the existing billingual programs and the survey of school principals and teachers. The same barrier is pointed out in other studies. The lack of qualified human resources can be breaken down into two directions: (1) lack of the qualified teaching resources and (2) lack of the qualified school administrators.

There are several interesting findings related to the lack of the qualifed teaching cadres: (1) Approximately $60 \%$ of the Georgian language teachers do not demonstrate sufficient competency in the Georgian language. According to the results of the Georgian language testing held in 2010 by the National Curriculum and Assessment Center, 65 \% of the teachers of the non-Georgian language schools do not know Georgian language (Melikidze, 2010 at Panel discussion at Ombudsman Office of Georgia). The Georgian-language competency among the teachers is particularly problematic in the regions compactly resided by ethnic minorities: Marneuli, Akhalkalaki, Ninotsminda, and Tsalka. Seventy to eighty percent of the teachers in these cities demonstrate the level 1 and 2 competency of the Georgian language (Center for Civil Integration and Inter-Ethnic Relations, 2011); (2) teachers demonstrate very low confidence in their ability to conduct billingial instruction. Ninety four percent of the subject teachers of the minority schools indicated that they do not know Georgian language and therefore are not able to teach in billingual programs; (3) apart from the barriers associated with the Georgian language competence, teachers of the minority schools have problems with the professional development in their subject areas. In the above-mentioned study only the primary, native language and Georgian language teachers responded positevely on the question about the participation in the professional development programs. Rest of the teachers indicated that they do not participate in any kind of in-service professional development programs.

In the study the special attention was given to the readiness of the teachers of social sciences to teach their subjects only in the state language. It was very important to research this area as according to the Law on General Education of Georgia, as of the academic year 2010-2011 social sciences are taught only in state language in minority schools. Interesting information was collected both from the teachers and school principals. Forty eight teachers out of 364 participants were teachers of the social sciences. According to the survey results, only 16 of 48 social science teachers speak Georgian (i.e., 33.3\% of the surveyed teachers). 
Moreover, when the teachers of the social science were asked whether they could to teach the discipline in the state language, only eight of them (16.67 \%) responded positively. Very similar information was obtained from the school principals. Only 20 participants out of 155 (12.9\%) principals responded that teachers of social sciences would be able to teach social sciences both in the native and state languages. These findings demonstrate that at this stage it is quite unrealistic to expect the teachers of social sciences to teach their discipline only in the state language.

Another important component of the issue of less qualified human resources is related to the lack of the relevant competence among the school principals. Out of all the principals of the target schools only three principals were informed about what kind of bilingual program was being implemented at their school. This means that $98.6 \%$ of the school principals have no information about the bilingual programs in general, as well as in the context of their own school. At the same time $90 \%$ of the principals indicated that they had participated in the trainings related to the bilingual education. This evidence once again suggests that despite certain professional development opportunities school principals have no readiness for the implementation of the bilingual programs.

\section{Multilingual Education Programs and School Community}

One of the findings of the study reports that out of the 155 target schools none had the school mission and strategic development plan outlining the school vision and strategy of the bilingual education. Lack of the shared vision of the bilingual education programs was also revealed when principals were asked whether they were planning to launch the bilingual education programs and why. Forty five percent of the 155 school principals responded that they were not planning to start the implementation of such programs. Those school principals, who were implementing or were planning to implement bilingual education programs indicated that they had taken such a decision as it was required by the Ministry of Education and Science of Georgia. Along the request of the Ministry of Education, 5\% of the schools also indicated the parent request. Two percent of the schools also reported the school competition for more students and more vouchers as one of the reasons for implementing bilingual education programs (it should be mentioned that due to the changes in the school financing system introduction of the bilingual education programs is no more considered as the financial incentive). Survey results also showed that majority of the teachers do not participate in the planning and implementation of the bilingual programs. Only the teachers of the Georgian language and literature reported to participate in these processes. Subject teachers are not involved in the planning process and accordingly do not share the value of the bilingual education programs.

\section{Parental Involvement in the Planning and Implementation of the Billingual Education Programs}

Given study showed interesting results on the involvement of the parents and the community. As it was already mentioned, only $2 \%$ of the school principals indicated that they introduced or were planning to introduce the billingual education programs based on the parent request. The analysis of the billiongual programs also revealed that mainly the Georgian language and literature teachers and representatives of the educational resource centers participate in the selection and planning of the billingual programs. It is also interesting to review the responses to the questions related to the parents involvement in school life. All of the school principals and teachers indicated that parents participate in the school life. However, 95\% of the school 
principals and $82 \%$ of the teachers could not answer the question about the specific programs, strategies and activities of parent involvement. These evidence explicitly suggests that parental involvement in the school life is very minimal. Moreover, even when parents are actively participating in the school life, they tend to be cautious about introducing billingual programs. This can be explained by the fact that majority of these parents do not speak the Georgian language and therefore in billingual programs they will not be able to help their children with the homework. Clearly, these parents could have benefited a lot if school had parent education and awareness-raising programs. Unfortunately, such kind of programs exist neirher in the Georgian, nor in the non-Georgian schools.

\section{Conclusion}

The findings of this research may become the significant foundation for the implementation of the bilingual education reform in Georgia. These findings suggest that existing situation is quite challenging for the implementation of the bilingual programs. At the same time, the results of the research advise the measures that have to be taken in order to maximize the positive impact of the bilingual education programs.

Given study revealed the problems that have to be solved at the national policy level. The ministry of education and science of Georgia demonstrates the improper understanding of the purpose and importance of bilingual education reform. Bilingual education is seen as part of teaching the state language. This is evidenced by the fact that the Ministry of Education made the bilingual education reform as part of one of its projects which is aimed teaching Georgian language. This approach is further strengthened by the statements of the Minister of Education and Science of Georgia. According to these statements, all non-Georgian schools will move to the bilingual education from 2011 and 30\% of the subjects will be taught in Georgian language. Exception will be non-Georgian schools in Tbilisi where 60\% of the subjects will be taught in Georgian and a year later-90\% of the subjects (Interview with the Minister of Education and Science, 2010). Despite the fact that the importance of the bilingual education was recognized in the context of teaching the state language, the main purpose and idea of the bilingual education should not be ignored - to develop a balanced bilingualism in each child without any academic problems and to provide the opportunity to receive the education in the native language. Historically bilingual programs are associated with the decreased dropout rates and academic underachievement of the minority students receiving education in the state language (in the language in which their competence is limited). The current vision of the Ministry of Education of Georgia which implies teaching the state language through the bilingual programs will in the best-case scenario lead Georgia to the results because of which the Western countries started to advocate such programs. Therefore, it is crucial that the Ministry of Education defines the goal of the bilingual education in Georgia to be the development of the bilingualism along with the overall academic success of each student and plans and implements the corresponding bilingual education programs. The Ministry of Education and Science should also revise its attitudes towards the submersion programs. The Ministry of Education and Science of Georgia is actively popularizing and stimulating submersion (Georgian program submersion) programs.

Revision of the bilingual education policy requires certain legislative changes. First of all, the benchmarks should be determined for the non-Georgian schools - what are these schools expected to achieve in a certain period of time? Secondly, it is very important to develop and adopt such state documents as national curriculum 
of Azerbaijani and Armenian languages, which are in line with the Georgian educational system. Thirdly, changes have to be made in the allocation of the instructional hours so that they correspond to the specific nature and characteristics of the bilingual education. Fourthly, amendment should be made to the maximum class-size in the bilingual programs. Fifthly, it is very important to create a professional standard of a bilingual education and to plan and implement both pre-service and in-service professional development programs according to this document. Finally, it will be necessary to create incentive system for the teachers in order to ensure recruitment and retention of the qualified teaching cadre in such schools.

One of the most important priorities is to ensure the active involvement of the parents and community in the school life. As the findings of this study non-Georgian schools have almost no practice of such involvement. Hence the professional development of the administrators and teachers in the area of parent and community involvement is very important. On the other hand, the non-Georgian schools can benefit a lot by implementing the parent education and awareness raising programs. Non-Georgian schools have got no sufficient financial and human resources for implementing such programs. However, very efficient programs can be implemented by the Ministry of Education and Science of Georgia in collaboration with the local and international organizations.

In conclusion, the Georgia education system and the minority integration policy have step by step reached the important point of launching a bilingual education reform. Expectations towards this reform are very high (Ombudsman Office, Meeting with Ethnic Minority Council, March 30, 2008). When expectations are high, chances of dissapointent are also very high. Dissapointment towards the billingual education reform may equal the disappointment to the policy of the integration of ethnic minorities. Therefore, it is crucial for all the parties involved to ensure the effectiveness of the bilingual education reform. The reform will be effective if state priority is given to the "strong" bilingual programs and appropriate policies and activities are implemented.

\section{References}

Baker, C. (2006). Foundations of bilingual education and bilingualism. Clevedon: Multilingual Matter.

Baker, K. A., \& De Kanter, A. A. (1983). Bilingual education. Lexington, MA: Lexington Books.

Bekerman, Z. (2005). Complex contexts and ideologies: Bilingual education in conflict-ridden areas. Journal of Language Identity and Education, 4(1), 1-20.

Bekishvili, N. (2010). Unexpected announcement of Dimitry Shashkin. Retrieved from http://liberali.ge/node/1114

Benson, C. (2004). Do we expect too much of bilingual teachers? Bilingual teaching in developing countries. International Journal of Bilingual Education and Bilingualism, 7(2\&3), 204-221.

Bilingual education-handbook for teachers. (2001). Riga: Latvian Language Agency.

Carrasquillo, A., \& Rodriguez, V. (2002). Language minority students in the mainstream classroom (Vol. 33). Clevedon: Multilingual Matters.

Center for Civil Integration and Inter-Ethnic Relations. (2011). Pre and post training assessment of GSL teachers. Tbilisi: CCIIR Publishing House.

Chomsky, N. (1965). Aspects of the theory of syntax. Cambridge: MIT Press.

Creese, A. (2004). Bilingual teachers in mainstream classrooms: Actioning difference and mediating diversity. International Journal of Bilingual Education and Bilingualism, 7(2), 189-203.

Cummins, J. (2000). Language, power, and pedagogy: Bilingual children in the crossfire (Vol. 23). Clevedon: Multilingual Matters.

Department of Statistics of Georgia. (2002). Statistical data on population of Georgia. Retrieved from www.geostat.ge

European Center for Minority Issues. (2009). The integration of national minorities in the Samtskhe-Javakheti and Kvemo Kartli provinces of Georgia: Five years into the presidency of Mikheil Saakashvili. Retrieved from http://www.ecmicaucasus.org /upload/publications/working_paper_44_en.pdf 
Fillmore, L., \& Snow, C. (2000). What elementary teachers need to know about language. Washington: Center for Applied Linguistics.

Garcia, O. (1991). Latinos and bilingual education in the United States: Their role as objects and subjects. New Language Planning Newsletter, 6(2), 35.

Grigule, L. (2010). Georgia minority education reform: From local initiatives towards state planned minority education reform. Bilingual Education, 2, 31-43.

Haworth, P., Cullen, J., Simmons, H., Schimanski, L., McGarva, P., \& Woodhead, E. (2004). The role of acquisition and learning in young children's bilingual development: A sociocultural interpretation. International Journal of Bilingual Education and Bilingualism, 9(3), 295-309.

Hornberger, N., \& Ricento, T. (1996). Unpeeling the onion: Language planning and policy and the ELT professional. TESOL Quarterly, 30(3), 401-428.

International Crisis Group. (2006). Armenian and Azeri Minorities in Georgia. Retrieved from http://www.crisisgroup.org/ /media /files/europe/178_georgia_s_armenian_and_azeri_minorities.pdf

Krashen, S. (1981). Second language acquisition and second language learning (Vol. 2). Oxford: Pergamon Press.

Lenneberg, E. H. (1967). The biological foundations of language. New York: John Wiley and Sons.

Lindholm-Leary, K. J. (2005). Review of research and best practices on effective features of dual language education programs. Retrieved from http://www.lindholm-leary.com/resources/review_research.pdf

Melikidze, M. (2010). Affirmative action policy in Admission System of Georgia. Retrieved from http://tolerantoba.ge/index.php?id=1314971931

Ministry of Education and Science of Georgia. (2009). Bilingual education strategy and action plan 2009-2014. Retrieved from www.mes.gov.ge.

Ministry of Education and Science of Georgia. (2010a). Multilingual education programs regulation. Retrieved from www.mes.gov.ge

Ministry of Education and Science of Georgia. (2010b). Statistical data of the Ministry of Education and Science of Georgia. Retrieved from http://mes.gov.ge/index.php?module=text\&link_id=141\&lang =geo

Ministry of Education and Science of Georgia. (2011). Statistical data of the Ministry of Education and Science of Georgia. Retrieved from http://emis.ge

Ministry of Education and Science of Georgia. (2013). Statistical data of the Ministry of Education and Science of Georgia. Retrieved from http://emis.ge

Ministry of Education and Science. (2011). News on increasing number of ethnic minorities enrolled in schools with Georgian language instruction. Retrieved from http://mes.gov.ge/content.php?id=2831\&lang=geo

Montecel, M. R., \& Cortez, J. D. (2002). Successful bilingual education programs: Development and the dissemination of criteria to identify promising and exemplary practices in bilingual education at the national level. Bilingual Research Journal, 26(1), $1-10$.

National Curriculum and Assessment Center. (2011). National curriculum of Georgia 2011-2016. Retrieved from http://www. mes.gov.ge/content.php?id=3929\&lang=geo

Ovando, C. J., Collier, V. P., \& Combs, M. C. (2003). Bilingual and ESL classrooms. Teaching in multicultural contexts (3rd ed.). New York: McGraw-Hill.

Parliament of Georgia. (2005). Law of Georgia on general education. Retrieved from www.mes.gov.ge

Perna, L. W., \& Swail, W. S. (2000). A view of the landscape: Results of the national survey of outreach programs. In Outreach program handbook 2001 (pp. xi-xxix). New York: The College Board.

Perna, L. W., \& Titus, M. (2005). The relationship between parental involvement as social capital and college enrollment: An examination of racial/ethnic group differences. Journal of Higher Education, 76(5), 485-518.

Shaw, P. (2003). Leadership in the diverse school. In C. Baker (Ed.), Foundations of bilingual education and bilingualism. Clevedon: Multilingual Matter.

Skutnabb-Kangas, T. (2000). Linguistic genocide in education-or worldwide diversity and human rights. Mahwah, NJ: Erlbaum.

Skutnabb-Kangas, T., \& Garcia, O. (Eds.). (1995). Multilingualism for all? General principles. Lisse, The Netherlands: Swets and Zeitlinger.

Tabatadze, S. (2008a). Bilingual educational policy in Georgia. Journal “Solidaroba”, (23), 66-80.

Tabatadze, S. (2008b). Education reform and non-Georgian language schools. Tbilisi: Caucasus Institute for Peace, Democracy and Development. 
Tabatadze, S. (2010a). Bilingual education programs in Georgia, what public schools can choose?. Journal Bilingual Education, (1), 7-21.

Tabatadze, S. (2010b). Intercultural education in Georgia. In Culture dialogue and civil consciousness (pp. 63-86). Tbilisi: Caucasus Institute for Peace, Democracy and Development.

Tabatadze, S. (2010c). New initiatives of education policy in the context of civil integration. Tbilisi: Caucasus Institute for Peace, Democracy and Development.

Tabatadze, S. (2011). Bilingual educational policy in Georgia. In Human diversity in education, integrative approach (pp. 282-284). New York: McGraw-Hill.

Tabatadze, S., \& Gorgadze, N. (2014). Intercultural sensitivity of primary school teachers of Georgia. International Journal of Education and Research, 6, 281-300

Teachers Professional Development Center. (2009a). Teachers professional standard. Retrieved from http://www.tpdc.ge/index. php?page=professional-standards \&hl=ge

Teachers Professional Development Center. (2009b). Teachers subject standards. Retrieved from http://www.tpdc.ge/index.php? page $=1-7-2 \& h l=g e$

Teachers Professional Development Center. (2010). Teachers professional development programs. Retrieved from http://www.tpdc. ge/index.php?page=1-3-7\&hl=ge

United Nations Association of Georgia. (2010). Monitoring results of implementation of the national concept and action plan on tolerance and civic integration. Retrieved from http://www.ecmicaucasus.org/upload/cnm/UNDP-Publication-ENG-FINAL. pdf

Varghese, M. M. (2004). Professional development for bilingual teachers in the United States: A site for articulating and contesting professional roles. Bilingual Education and Bilingualism, 7(2\&3), 222-238. 